\title{
The Humeitepe Harbour at Miletus: An analysis of its infrastructure
}

\section{Maurice Thurn B.A.}

Universität Hamburg, Institut für Archäologie und Kulturgeschichte des antiken Mittelmeerraumes, email: Maurice.Thurn@web.de

\begin{abstract}
This paper represents a chapter of my master thesis The harbours of Miletus - An analysis of their infrastructure. The aim of this work is to examine the harbours of the polis Miletus in Asia Minor, with special attention on their infrastructure. Here I will focus on the harbour at the east bay of the Humeitepe, one of the most overlooked ones. The results of research, both from excavation and geophysical survey over the past twenty years, shed new light on the harbour. By reevaluating this dataset, the image of a prosperous trading harbour during the late Hellenistic and Roman Imperial era becomes evident.
\end{abstract}

Key words

Harbour, Asia Minor, Infrastructure

\section{Introduction}

Miletus is situated on the Ionian west coast of modern Turkey. It used to be a thriving polis from archaic times to the end of the Byzantine empire that stretched over a peninsula in the Latmian Gulf. Due to heavy delta progradation of the river Maeander (turk. Büyük Menderes) today the site is 
completely cut off from the sea around $7 \mathrm{~km}$ from the coast. However, even today, it is still possible to identify the bays that could accommodate possible harbours. The current state of research names four harbours in the city area for the classical period up to late antiquity: on the western side the so-called Theatre Harbour, in the northwest the famous Lion Harbour, in the northeast the Humeitepe Harbour and to the east of the city centre the so-called East Harbour (Fig. 1). The harbours of Miletus have repeatedly been the subject of research in the more than 120-year long history of excavation but, with the exception of the Lion Harbour, they have never been in the centre of interest in the same way as the central public buildings such as the Bouleuterion and the theatre or the exploration of the archaic city.

\section{Research Questions and Methodology}

Previous research about the harbours of Miletus has focused strongly on aspects of representation of the Lion Harbour. Studies were carried out to examine how the harbour basin and its adjoining buildings fit into the cityscape rather than how this affected trade (Bouras, 2012; Brückner et al. 2014; Pirson, 2014; Schupp, 2014; Feuser, 2014; Wawrzinek, 2016; Radloff, 2019). My work changes the perspective by focusing on the infrastructure of the harbours. The Humeitepe Harbour in particular has only recently been attracting attention and a complete list of all known buildings belonging to the harbour complex has not yet been published. The aim of this paper is therefore to first individually analyse those structures that can be allocated to the harbour complex. In order to achieve this, on the one hand the research published so far must be evaluated; on the other hand, the results of the geophysical surveys, carried out in Miletus since the early 1990s, offer the opportunity to examine the area for further, as yet unexplored structures. Based on these individual analyses, the chronological development of the infrastructure shall then be examined and conclusions about trade will be drawn from the infrastructure.

The harbour complex considered here includes not only harbour-specific buildings, but also areas immediately adjacent to them, which were connected to the harbour basin by pathways. According to S. Feuser, only breakwaters, piers, quay walls, ship houses and lighthouses are harbour-specific buildings. Other buildings known from harbour cities, such as porticoes, warehouses, and gate buildings, are seen as part of the conventional cityscape (Feuser, 2020: 229). However, since these harbour-specific buildings alone do not allow us to deduce the infrastructural aspects of this study, the other buildings must also be examined, analysed and evaluated with regard to their relation to the harbour. Special attention needs to be paid to those buildings which could be assigned a function as mercantile building. Decisive for this are above all those with adjoining chambers which are generally referred to as tabernae (Emme, 2013: 52f). 


\section{The Humeitepe Harbor}

The large hill called Humeitepe in the north of polis received little academic attention for a long time. Only the temple at the northern tip, attributed to Demeter, was investigated more thoroughly from the late 1970s onwards. Otherwise, excavations were limited to test trenches at the beginning of the excavation activities. In 1968, G. Kleiner was the first to suspect a harbour at the eastern bay of the Humeitepe (Kleiner, 1968; 8) The geophysical surveys conducted since the early 1990s were able to provide much more information (Fig. 2). Not only was a road network, which extended over the entire hill, discovered, but also a large number of structures was revealed, some of which indicate a harbour on the eastern bay (Bumke and Tanriöver 2017: 123-126). Based on the results of the geophysics, an excavation was carried out in 2011 under the direction of $\mathrm{H}$. Bumke and the results verified a harbour at the suspected site (Bumke and Tanriöver 2017: 171).

\section{The Harbour Basin}

The potential harbour basin comprises the striking eastern bay of the Humeitepe, measuring about $200 \mathrm{~m}$ from $\mathrm{N}$ to $\mathrm{S}$ and $60 \mathrm{~m}$ from $\mathrm{W}$ to $\mathrm{E}$ (Fig. 2). This bay is protected from winds in the lee of the peninsula and is additionally bordered by the former islands Büyük Çakmar-Tepe and Küçuk ÇakmarTepe, which have been connected to the mainland since the 1st or 2nd century AD (Brückner et al . 2017: 886). This process of landlocking expanded the harbour basins even further to the west. Geoarchaeological drillings in the bay provided information about the sedimentation process and show that landing of ships would have been possible at this place from archaic times onward and that the bay was accessible by ship until the late Roman-Byzantine period, perhaps even later (Tuttahs 2007: 356-358).

\section{The Harbour Gates}

The geophysical surveys carried out on the Humeitepe from 2003 to 2005 clearly revealed the city wall in the eastern bay and two roads leading to it from the northwest and southwest. At the intersections Stümpel and Erkul postulated gates (Stümpel and Erkul 2008: 25; Fig 2, HGs and HGn). At the southern of these postulated intersections H. Bumke carried out an excavation in 2011. In the process she uncovered a gate made of marble blocks (Fig. 2, HGs; Fig 3). Five layers of marble slabs were found in situ, resulting in a preserved height of the gate of $1.80 \mathrm{~m}$ (Fig. 4). Based on mortar remains on 
the uppermost layer and isolated blocks that were discovered during the excavation, Bumke proposes that there are still more layers to be reconstructed. The clear width of the passageway is $3 \mathrm{~m}$. The marble blocks were in secondary use, which fits to the construction of the gate, which was integrated into an already existing gneiss wall on top of which the marble slabs were laid. Care was taken to maintain the uniform appearance of the wall by using marble slabs of similar height as the gneiss blocks. This was only broken up by the fact that the marble slabs were installed slightly offset to the rear. Thus, on the one hand the new is emphasized, on the other hand the old is preserved. Towards the sea side, two marble threshold blocks as well as an iron door pan were found in situ. The gate could therefore be closed by a double-winged door. The signs of wear on these threshold blocks indicate that there was heavy traffic by wagons (Bumke and Tanriöver 2017: 133-141). Besides the gate being located at an important road intersection, connecting the harbour with the city, two finds underline the significance of the gate for the Humeitepe as a settlement area and the importance of the Humeitepe Harbour for it. One is a $2 \mathrm{~m}$ high and $0.59 \mathrm{~m}$ wide marble slab which depicts a caryatid in high relief. Bumke and Tanriöver believe that this high relief flanked an arch on the right side and had a counterpart on the left. This would further enhance the architectural value of the harbour gate (Bumke and Tanriöver 2017: 152-158). Second, a 1.25m high and $0.63 \mathrm{~m}$ wide inscription stele was found, which is almost

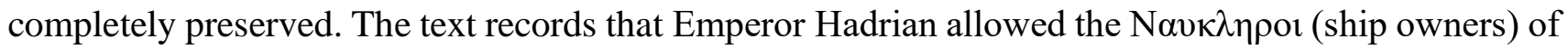
Miletus to establish an associationi. Ehrhardt and Günther postulate that the inscription was placed on the gate itself, at eye level of the passing people (Ehrhardt and Günther 2013: 199). Thus, this inscription, at least in the imperial period, speaks for the relevance of the Humeitepe Harbour for trade

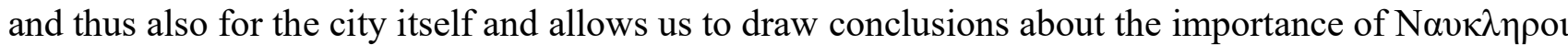
(ship owners) within Milesian society (Ehrhardt and Günther 2013: 208-211). Through comparisons with the Great Harbour Monument and the harbour gate at the Lion Harbour, Bumke and Tanriöver date the installation of the Humeitepe Harbour gate to the 1st century BC, based on the use of rectangular blocks with reused stones and the utilisation of mortar for levelling layers (Bumke and Tanriöver 2017: 146). However, they do not rule out the renovation of an already existing gate at this time (Bumke and Tanriöver 2017: 141). An exact date for the much older gneiss wall in which the gate was built could not be determined based on the archaeological findings. They therefore suggest a date in archaic times with reference to the discussion about the fortification of the polis in general and the Humeitepe in particular (Bumke and Tanriöver 2017: 141-144.). This view contradicts earlier results, which rejected an archaic phase for the fortification of the Humeitepe and advocated for construction in Hellenistic times (Blum 1999: 69-71). Whether the observations and considerations about the southern gate also apply to the northern one visible in the geomagnetics (Fig. 2 HGn) cannot be answered at this point. Bumke and Tanriöver speculate that this access might be attributable to an 
earlier phase and that further excavations at this site are crucial in order to gain more detailed information (Bumke and Tanriöver 2017: 147.).

\section{The Piers}

Following the extension of the roads through the gates, two anomalies (Fig. 2, P1 and P2) extend about $20 \mathrm{~m}$ long and about $3.50 \mathrm{~m}$ wide into the harbour basin. Stümpel and Erkul suspect structures that can be interpreted as piers (Stümpel and Erkul 2008: 25). This interpretation seems to be reasonable, especially if it has to be assumed that the Humeitepe Harbour was an important harbour for trade, especially in the imperial period (see below). At that time, the use of hydraulic opus caementitium for the construction of piers in the water would not be surprising, as numerous examples from this period, including Alexandria Troas (Feuser 2011: 263-265) and Caesarea Maritima (Feuser 2020: 156-159) show. However, large limestone blocks are also conceivable as building material, as was found on the not dissimilar piers in the nearby harbour of Ephesus (Feuser 2020: 126). An investigation of these anomalies by excavations or drillings has not been carried out so far but is desirable.

\section{The Harbour Baths}

To the north-west of the southern harbour gate, the recognisable ruins of a large building can still be seen (Fig. 2, HB). The geophysical survey carried out in 2012 confirmed the building complex as a bath facility. The data of the georadar show a wing with smaller rooms in the north and a larger room in the south. Judging from these results, the complex can be compared to the bath to the south of the Südmarkt in Miletus. This bath was excavated in 2009 and revealed two phases, one from the imperial era and one from the late 5th century AD. Similar to the results from the complex at the Humeitepe, the building at the Südmarkt has a wing with smaller rooms in the north and a southern, larger longitudinal room. Furthermore, the two baths are comparable in size, so that the picture is one of smaller baths, which were rather simple and served the surrounding districts. Niewöhner assumes that the relatively small complex may have served primarily for the personal hygiene of the inhabitants of Humeitepe and the sailors of the adjacent harbour (Niewöhner 2013: 170-175). Even if these parts of the population used the facilities of the baths, it is more likely that they were built there not necessarily in connection with the infrastructure of the harbour but due to its location at the lowest point of the Humeitepe, so that it was connected to the water supply through the aqueduct. 


\section{The Stacking Area}

Southeast of the southern harbour gate, geomagnetics reveal a larger open space, which clearly stands out from the buildings of the surrounding insulae (Fig. 2, SA). The space measures approximately $52 \mathrm{~m}$ x $62 \mathrm{~m}$, about the area of two insulae. In the north it is enclosed by the city wall, in the west, east and south by roads. So far, no peripheral buildings have been detected and therefore the space should not be classified as an agora. A similar situation has been detected in Alexandria Troas: immediately adjacent to the harbour basin is a level area in the otherwise ascending terrain, bordered on its sides by columns, so that a square-like open space is created. Feuser associates this open space with a stacking area, since the area directly in front of the quay wall is very narrow and would not have been a good place for the temporary storage of the goods (Feuser 2009: 60; 124). In analogy to Alexandria Troas, the open space at the Humeitepe can be understood as a kind of stacking area, where goods were temporarily stored under the open sky for transhipment. As in Alexandria Troas, at the Humeitepe Harbour the space between the sea and the city wall would have been limited as well, so that such a stacking area in an open space seems to be indispensable.

\section{The Hall at Humeitepe Harbour}

Immediately north of the harbour baths, the results of the geomagnetic survey show an elongated building divided into adjoining chambers (tabaernae) (Fig. 2, H). The approximately 60m long and $6 \mathrm{~m}$ wide building is oriented with its long side to the street grid of the Humeitepe. During the 2011 campaign H. Bumke excavated a part of this building as well. Even though this trench was not completed, the geomagnetic picture could be confirmed (Figure 5). A $3.58 \mathrm{~m}$ long and about $0.50 \mathrm{~m}$ wide wall of quarry stones and bricks in a mortar composite could be detected, which could not be followed up in the southeast. In the northwest, however, its end was found. From both sides of this wall, two other walls, each about $0.60 \mathrm{~m}$ long and $0.55 \mathrm{~m}$ wide, extended toward the northeast and southwest. These walls obviously constituted the entrance, so it can be concluded that the excavation cut into one of the chambers of the building. Bumke and Tanriover therefore correctly conclude that it is a mercantile building. The building would therefore be open to the west and the rear wall would face the city wall that runs along this site (Bumke and Tanriöver 2017: 147-149). They date the building to the Roman Empire from the 2nd to the early 3rd century AD on the basis of the masonry and the found pottery. According to them, the building was abandoned in the last third of the 3rd century AD, which they confirm with the found pottery (Bumke and Tanriöver 2017: 149) 


\section{The Routing at the Humeitepe Harbour}

From the harbour basin outside the city wall, with the piers used for the berthing of ships (Fig.2, P1 and P2), two paths lead into the city, one in the north (Fig. 2, S1) and one in the south (Fig.2, S2). The streets leading to the harbour gates break out of the hyppodamian street grid. The northern road meets a crossroad from which the temple dedicated to Demeter, located further north at the top of the Humeitepe, and the mercantile buildings, immediately west of the city wall (Fig. $2 \mathrm{H}$ ), could be easily reached. At the southern entrance is a concentration of several structures with different functions: to the north, the mercantile buildings already mentioned, as well as the harbour baths (Fig.2. HB), which

probably served the harbor workers' demand for personal hygiene. To the southeast is the stacking area (Fig.2 SA), which served for the short-term storage and preparation of the ships' cargo. The geomagnetic data gives hints for connection to the city centre. The road (Fig.3, S3), which starts exactly at the southwest corner of the bath and the mercantile building behind it leads directly towards the Delphinion and the city centre, over an approximately $18 \mathrm{~m}$ high hilltop. It is clear that the infrastructural facilities were arranged in such a way that they were well interconnected by the existing road system. This greatly enhanced the flow of goods and people in and around the harbour as well as the connection to the city centre.

\section{The Harbour at Humeitepe - An Imperial Trading Place}

The chronological development of the harbour area on the Humeitepe is extremely complicated due to the small amount of secure evidence from excavations. Therefore, only the results of the excavations of 2011 and the preliminary results of a survey conducted in 2014/15 on the Humeitepe under the direction of Ch. Berns offer clues (Huy and Weissova 2020). Based on the transport amphorae found, the preliminary results of this survey indicate that the Humeitepe must have been considered a place of trade as early as the 3rd century BC (Huy and Weissová 2020: § 39). From the 2nd century BC onwards, there is a significant increase in transport amphorae, especially from Knidos and Rhodes, with a particularly noticeable increase in amphorae from more distant regions from the 1st century BC onwards (Huy and Weissová 2020: § 43). This coincides with the dating of the installation of the southern harbour gate in the 1st century BC. Thus, development of the area as an intensively used harbour can be assumed from this time at the latest. The preliminary results of the survey show a slight decrease in transport amphorae for the imperial period. However, the fact that these no longer originate only from the Aegean region but also from both the eastern and western Mediterranean underlines the relevance of the Humeitepe Harbour for the trade of the polis (Huy and Weissová 2020: § 45). This is

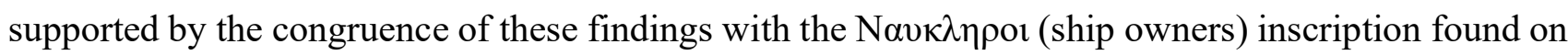


the harbour gate, dated to the early 2 nd century $\mathrm{AD}$, and the construction of the hall in the course of the 2 nd century AD. If one accepts the proposition that the anomalies described above are piers that lead into the harbour basin, one is tempted to associate them with the use of hydraulic mortar, as evidenced by numerous piers of the imperial era, such as those at Alexandria Troas (Feuser 2011: 263265). Furthermore, the comparison of the open space mentioned above to Alexandria Troas provides a further indication of its use as a stacking area during this period. In these cases, however, only a complete excavation and analysis of the structures can provide clarification. The preliminary results of the survey as well as the excavation of the hall offer clues, if not to the abandonment, then at least to the reduction of the importance of the harbour area, since the research proves a decrease of the transport amphorae and an abandonment of the hall in the period from the 3rd century onwards (Huy and Weissová 2020: § 47).

For the harbour area at Humeitepe, a chronological picture of latent trade in the Late Classical and Early Hellenistic period is thus presented. From the 1st century BC onwards, a clear upswing can be observed due to the ceramics finds and the installation of the harbour gates. This development is underlined by the construction of further buildings such as the hall and the manifestation of the significance of the area for the people trading there by the installation of the inscription plate by

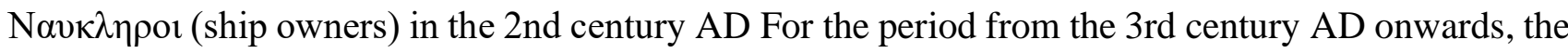
finds indicate a gradual decline in the volume of trade conducted there and a concomitant loss of significance.

What does this mean for the infrastructure and thus for the logistics of trade at the Humeitepe Harbour? First of all, it seems that in the 1st century BC a structurally defined infrastructure had to be created or at least extended. In earlier times, trade did not seem to have been sufficiently developed to require a structurally manifest infrastructure. Two entrance situations to the harbour indicate that the area was highly frequented from at least the 1st century BC onwards. This is also supported by the anomalies oriented towards the gates, which could be piers made of opus caementitium, which simplified the docking and unloading of larger ships. As the space between the city wall and the water was quite narrow and the piers, with a width of $3.50 \mathrm{~m}$, were not large enough to store large quantities of goods, the use of a stacking area south of the harbour was a logical choice. Located directly at the road leading to the piers, the goods to be shipped could easily be brought to the ships, or incoming goods could be stored temporarily before they were distributed further into the city, or to other ships passing up the Maeander River. From the 2nd century AD onwards, a hall with tabernae was added to the harbour area. Due to the multifunctional nature of this type of building, a variety of uses such as storage and sales rooms, workshops or meeting points for local groups must be assumed here. The harbour and the 
hall are directly connected by the road. Starting from the piers, an axis of pier - gate - street is formed, at the ends of which a cross street (Fig. 2, S3) joins with the hall as a connecting element. This crossroad then leads south over the hill, towards the Delphinion, and thus connects the Humeitepe to the city centre.

\section{Conclusion}

The research carried out until now allows us to reconstruct the basic elements of the infrastructure and shows the picture of a harbour which, despite its remote location, seems to have played an important role within the late Hellenistic and Roman polis. The stacking area and the hall in particular demonstrate that the harbour facilities have been allocated a substantial amount of space. Although these cannot compete with those in the Lion Harbour or East Harbour, they nevertheless testify to a considerable volume of trade, especially in conjunction with the results of the survey. However, this paper aims to underline the potential that the Humeitepe Harbour offers for further research. Almost none of the structures described above has been fully investigated. Especially with regard to the fine chronology, further insights into the development of the harbour area can be gained. Also, the method of construction of the piers and the northern gate are of great interest. These areas promise to be highly fruitful of further significant results and could be investigated in the future through means of excavation or geoarchaeological drillings. As part of my master's thesis, I would like to further investigate the integration of the harbour at the Humeitepe within the cityscape and the chronological and functional interplay of the individual harbours. In this, the development of the Humeitepe Harbour is only a small part of the overall picture of the littoral cityscape of Miletus.

\section{Acknowledgements}

For this work I used evidence provided by the excavations of Miletus conducted by Hamburg University with permission of the Turkish Directorate General for Cultural Heritage and Museums. I would like to thank my supervisor Prof. Dr. Ch. Berns, who kindly gave me permission to work on this topic, and my Co-Supervisor Dr. S. Huy for their support and feedback. Furthermore, I wish to express my gratitude towards the organisers of MAGS 2020 for letting me participate at this marvelous conference and the Honor Frost Foundation for the possibility to publish my work in the Short Report Series. 


\section{Reference List}

Berns, C., 2015, Forschungen in Milet: Rückblick und Perspektive, in Yalçin Ü. and Bienert H.-D. (ed), Anatolien - Brücke der Kulturen. Aktuelle Forschungen und Perspektiven in den deutschtürkischen Altertumswissenschaften. Tagungsband des Internationalen Symposiums „Anatolien Brücke - Brücke der Kulturen“ in Bonn vom 7. bis 9. Juli 2014, Der Anschnitt, Beiheft 27, 311-324. Blum, I., 1999, Die Stadtmauern von Alt-Milet. Ergebnisse des Survey 1996 und 1997. Archäologischer Anzeiger 1999, 53-76.

Bouras, C., 2012, Les portes entre le port et la ville, in Chankowski, V. and Karvonis, P. (ed), Tout vendre, tout achêter. Structures et équipements des marchés antiques. Collection Scripta Antiqua 42, 141-150. Bordeaux.

Brückner, H., Herda, A., Müllenhof, M., Rabbel. W. and Stümpel, H., 2014, On the Lion Harbour and other harbours in Miletos: recent historical, archaeological, sedimentological, and geophysical research. Proceedings of the Danish Institute at Athens, vol. VII, 49-103.

Brückner, H., Herda, A., Kerschner, M., Müllenhoff, M. and F. Stock, 2017, Life cycle of estuarine islands From the formation to the landlocking of former islands in the environs of Miletos and Ephesos in western Asia Minor (Turkey) in: Journal of Archaeological Science: Reports, 12: 876-894.

Bumke, H., and Tanrı̈ver, A., 2017, Der Hafen am Humeitepe in Milet. Ergebnisse der Ausgrabungen 2011. Archäologischer Anzeiger 2017/2, 123-177.

Ehrhardt, N. and Günther, W., 2013, Hadrian, Milet und die Korporation der milesischen Schiffseigner. Zu einem neu gefundenen kaiserlichen Schreiben. Chiron 34, 199-220.

Emme, B., 2013, "Das Märchen von den drei Märkten" Bauten merkantiler Funktion und die städtebauliche Entwicklung des hellenistischen Milet. Istanbuler Mitteilungen 63, 51-74.

Feuser, S., 2009, Der Hafen von Alexandria Troas. Bonn.

Feuser, S., 2011, The Roman Harbour of Alexandria Troas, Turkey. International Journal of Nautical Archaeology 40.2, 256-273.

Feuser, S., 2014, Überlegungen zur Gestaltung von Wegen und Räumen in kaiserzeitlichen Hafenstädten des Mittelmeerraumes, in Kurapkat, D., Schneider, P. I., and Wulf-Rheidt, U. (ed), Die Architektur des Weges Gestaltete Bewegung im gebauten Raum Internationales Kolloquium in Berlin vom 08. - 11. Februar 2012 veranstaltet vom Architekturreferat des DAI, 66-85. Regensburg.

Feuser, S., 2020, Hafenstädte im Östlichen Mittelmeerraum vom Hellenismus bis in die Römische Kaiserzeit: Städtebau, Funktion und Wahrnehmung, Urban Spaces 8. Berlin. 
Huy, S. and Weissová, B., 2020. An Urban Survey of Humeitepe, Miletus: Methodology and Preliminary Results. The Fieldwalker.org. Wilkinson T. C., and Schlawisch (Ed.), A., URL: https://www.fieldwalker.org/articles/aegean/002_huy_weissoval. Accessed on 2020-04-04.

Kleiner, G., 1968, Die Ruinen von Milet. Berlin.

Niewöhner, P., 2013, Neue spät- und nachantike Monumente von Milet und der mittelbyzantinische Zerfall des anatolischen Städtewesens, Archäologischer Anzeiger 2013/2, 165-233.

Niewöhner, P., 2016, Die Byzantinischen Basiliken von Milet, Milet 1.11. Berlin/Boston

Pirson, F., 2014, Antike Hafenstädte - Gestaltung, Funktion, Wahrnehmung, in S. Ladstätter, S, Pirson, F., and Schmidts, T., (ed.), Harbors and Harbor Cities in the Eastern Mediterranean, BYZAS 19, 619-643. Istanbul.

Radloff, L., 2019, ,Placing' a Maritime Territory at Hellenistic Miletos, in Döhl, R., and Jansen van Rensburg, J., (ed.), Signs of Place. A Visual Interpretation of Landscape, Berlin Studies of the Ancient World 69, 99-120. Berlin.

Schupp, M., 2014, Caput Ioniae. Zur Untersuchung römischer Hafenfassaden am Beispiel von Milet, in S. Ladstätter, S, Pirson, F., and Schmidts, T., (ed.), Harbors and Harbor Cities in the Eastern Mediterranean, BYZAS 19, 645-668. Istanbul

Stümpel, H., and Erkul, E., 2008, Geophysikalische Prospektion in Milet 2003-2005, Archäologischer Anzeiger 2008/2, 25-32.

Tuttahs, G., 2007, Milet und das Wasser: ein Leben in Wohlstand und Not in Antike, Mittelalter und Gegenwart, Schriften der Deutschen Wasserhistorischen Gesellschaft Sonderband 5. Siegburg.

Wawrzinek, C., 2016, Tore zur Welt. Häfen in der Antike. Darmstadt.

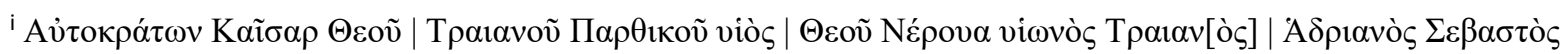

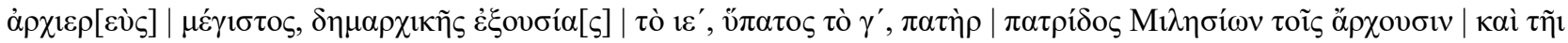

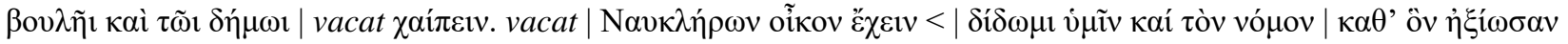

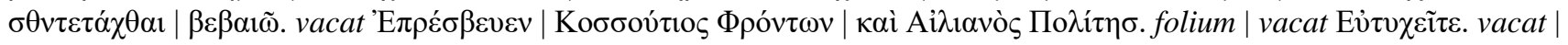

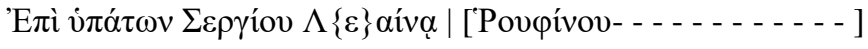

Transl.: Emperor Caesar Traianus Hadrianus Augustus, son of the deified Traianus Parthicus, grandson of the deified Nerva, high priest (pontifex maximus), holder of the tribunic power for the 15th time, Consul for the 3rd time, Father of the Fatherland, greets the officials, the Council and the people of Miletus.

(The right to own) an association of shipowners, I grant you and confirm the statutes by which they have requested to be constituted. were envoys: Cossutius Fronto and Aelianus Polites Farewell!
}

In the consular year of Sergius Laenas Pontianus and M. Antonius Rufinus - - - -

Text and translation according to Ehrhardt - Günther 2013, 200.

\section{Figures}




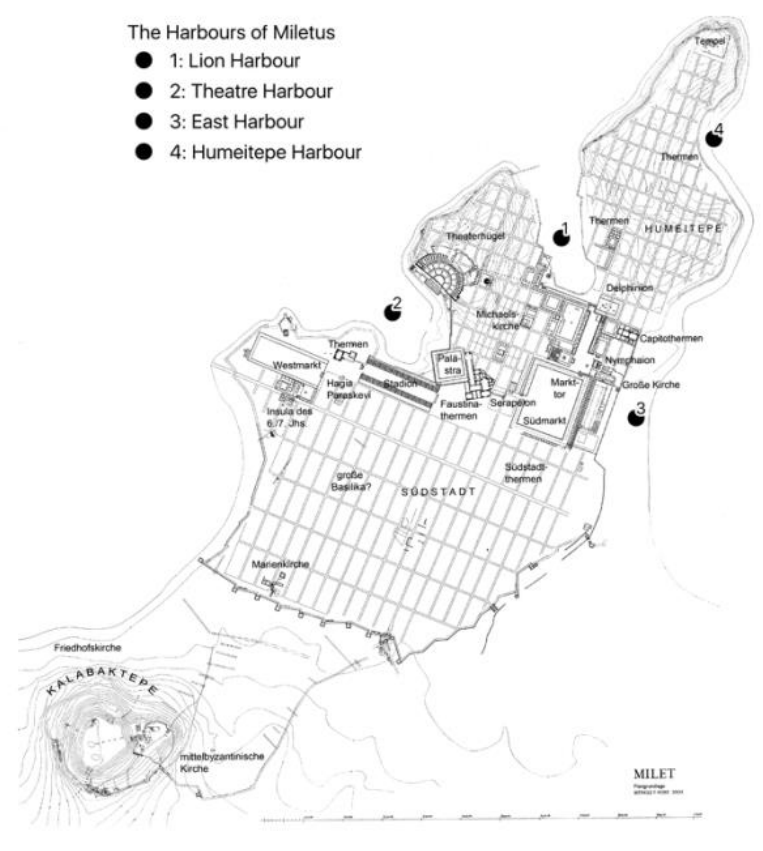

Figure 1: Map of Miletus with the harbours of Classical to Imperial times (Niewöhner 2016: Abb. 83; modified by M.Thurn)

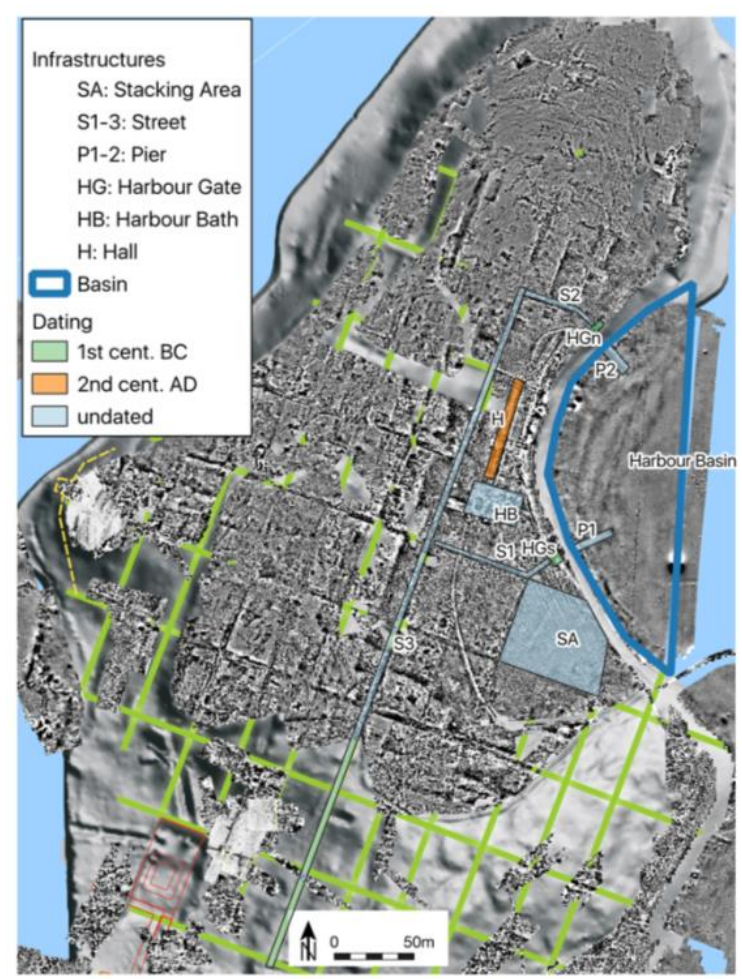

Figure 2: Geomagnetic map of the Humeitepe (Berns 2015: Abb. 6; modified by M. Thurn) 


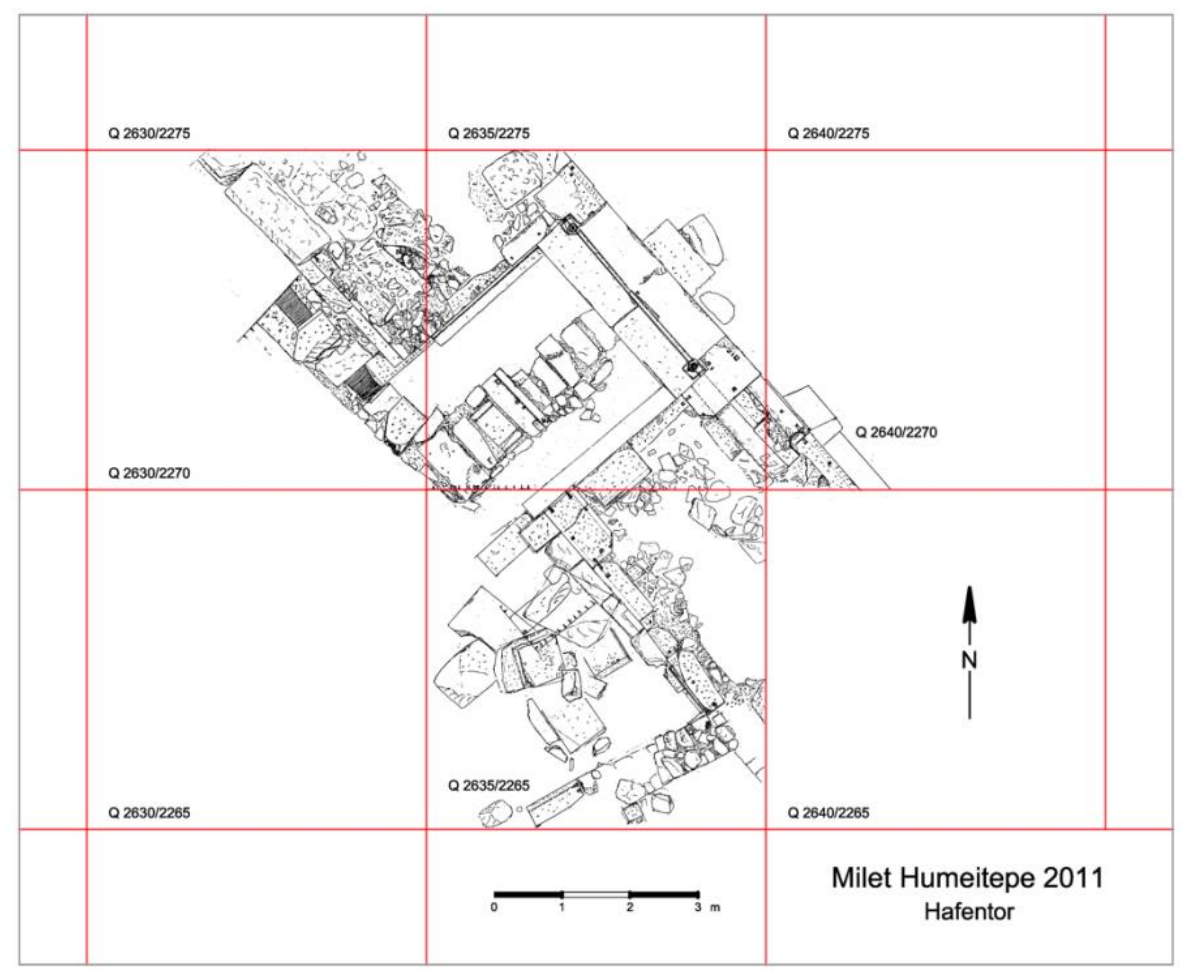

Figure 3: Drawing of the southern harbour gate (Bumke and Tanriöver 2017: Abb. 31, H. Birk based on I. Blum)

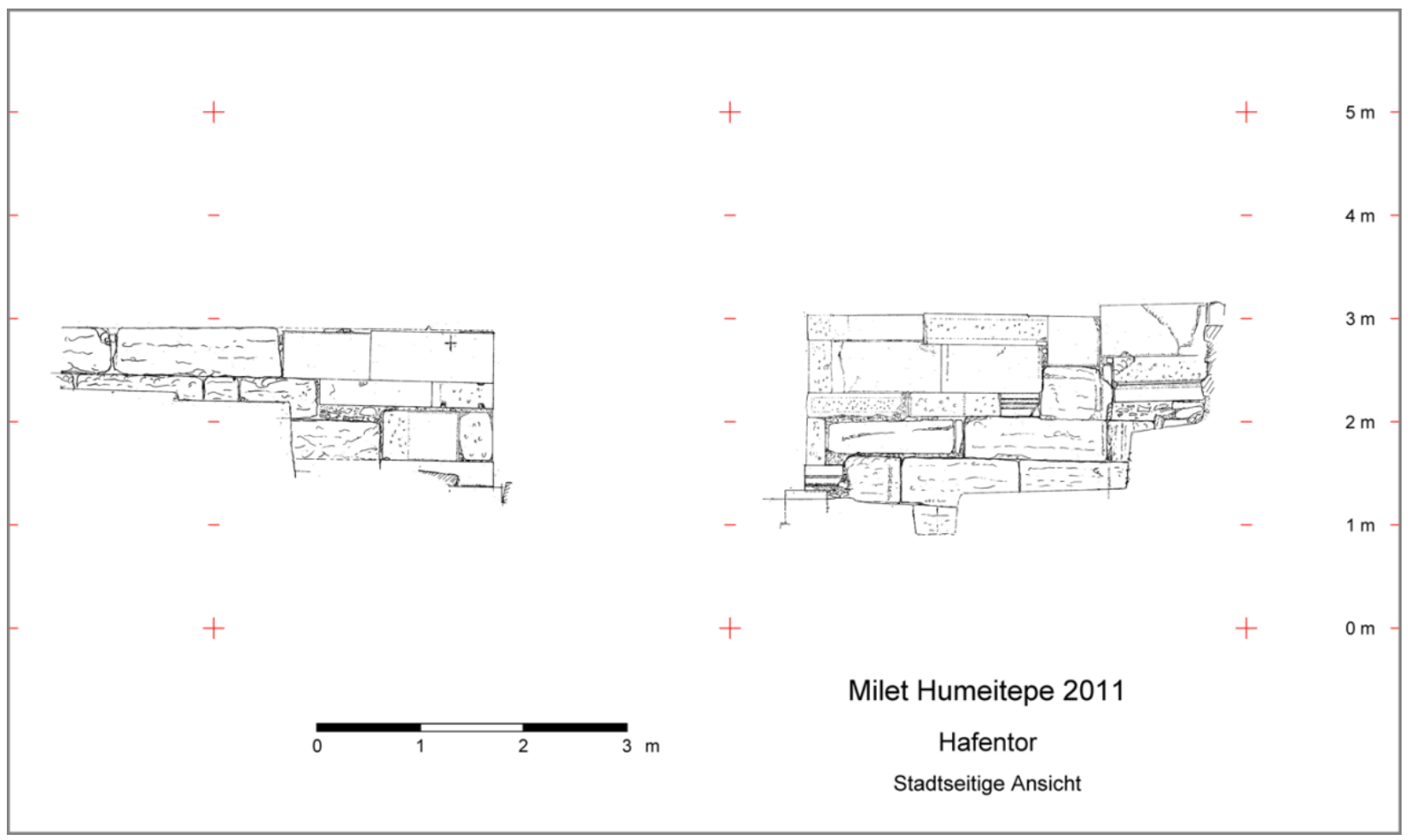

Figure 4: Drawing of the western side of the southern harbour gate (Bumke and Tanriöver 2017: Abb. 16, H. Birk based on I. Blum) 


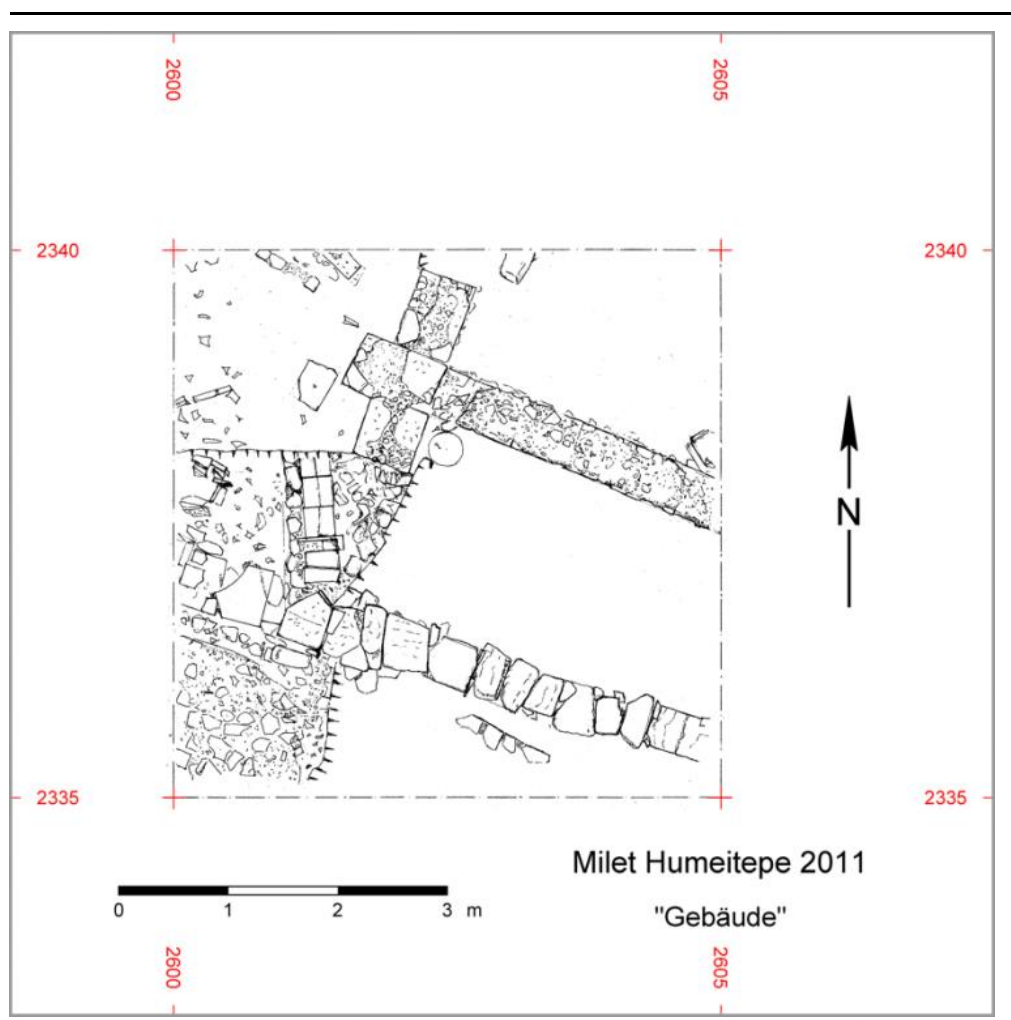

Figure 5: Drawing of a part of the hall at the Humeitepe Harbour (Bumke and Tanriöver 2017: Abb. 36, H. Birk based on I. Blum) 